\title{
Stable nitrogen and carbon isotope ratios in multiple tissues of the northern fur seal Callorhinus ursinus: implications for dietary and migratory reconstructions
}

\author{
Carolyn M. Kurle ${ }^{1, *}$, Graham A. J. Worthy ${ }^{2, * *}$ \\ ${ }^{1}$ National Marine Mammal Laboratory, Alaska Fisheries Science Center, National Marine Fisheries Service, NOAA, \\ 7600 Sand Point Way NE, Seattle, Washington 98115, USA \\ ${ }^{2}$ Physiological Ecology and Bioenergetics Laboratory, Texas A\&M University at Galveston, 5001 Avenue U, Suite 105, Galveston, \\ Texas 77551, USA
}

\begin{abstract}
We investigated changes in trophic level and feeding location over time in juvenile male northern fur seals Callorhinus ursinus from the Pribilof Islands, Alaska, using stable nitrogen $\left(\delta^{15} \mathrm{~N}\right)$ and carbon $\left(\delta^{13} \mathrm{C}\right)$ isotope analyses of their fur, muscle, blubber, brain, liver, and kidney tissues. Mean $\delta^{15} \mathrm{~N}$ values were non-uniform between tissues and ranged from $14.9 \%$ (fur) to $17.1 \%$ (lipid extracted blubber). Mean $\delta^{13} \mathrm{C}$ values also varied with tissue type and ranged from $-24.7 \%$ (non-lipid extracted blubber) to $-17.5 \%$ (fur). Mean isotope values of tissues clustered into groups coincident with their estimated protein and isotope turnover times, with fur representing the most remote incorporation of isotopic data, followed by muscle $\left(\delta^{15} \mathrm{~N}=15.1\right.$ to $15.6 \%$; $\left.\delta^{13} \mathrm{C} \approx-18.1 \%\right)$, brain $\left(\delta^{15} \mathrm{~N} \approx\right.$ $17.0 \%$; $\delta^{13} \mathrm{C}=-18.4$ to $-18.1 \%$ ), blubber $\left(\delta^{15} \mathrm{~N}=17.1 \%\right.$; $\delta^{13} \mathrm{C}=-19.7 \%$ o to $-18.1 \%$ ), kidney $\left(\delta^{15} \mathrm{~N} \approx\right.$ $16.4 \%$; $\delta^{13} \mathrm{C}=-18.5$ to $-18.2 \%$ ), and liver $\left(\delta^{15} \mathrm{~N}=16.0 \%\right.$ to $16.2 \%$; $\delta^{13} \mathrm{C}=-18.4 \%$ o to $-18.2 \%$ ). Mean kidney and liver $\delta^{15} \mathrm{~N}$ values ( 16.3\%) indicated that juvenile males from St. Paul and St. George Islands were feeding at the same trophic level during summer 1997. Mean kidney and liver $\delta^{13} \mathrm{C}$ values suggested that juvenile males from St. George Island $\left(\delta^{13} \mathrm{C}=-18.2 \%\right)$ were feeding at the Bering Sea shelf break, while juvenile males from St. Paul Island $\left(\delta^{13} \mathrm{C}=-18.5 \%\right)$ were feeding more on the continental shelf. Comparing $\delta^{15} \mathrm{~N}$ ratios of fur with $\delta^{15} \mathrm{~N}$ values from all other tissues allowed us to estimate that juvenile males were at their lowest trophic level when they were at the youngest age ( 2 yr old) targeted in this study. Mean $\delta^{15} \mathrm{~N}$ values from tissues collected opportunistically from 2 nulliparous females ( $\delta^{15} \mathrm{~N}$ values ranged from $16.1 \%$ for muscle to $18.0 \%$ for blubber) and 2 postparturient females $\left(\delta^{15} \mathrm{~N}\right.$ values ranged from $16.1 \%$ for muscle to $18.9 \%$ for blubber) suggested that, at all times, females were feeding at higher trophic levels than juvenile males. Lipid-extracted blubber samples from juvenile males had much higher $\delta^{15} \mathrm{~N}$ values $(17.1 \%)$ and $\delta^{13} \mathrm{C}$ values $(-19.7$ to $-18.1 \%$ ) than non-lipid extracted blubber $(\sim 16.0$ and $\sim-24.7 \%$, respectively), underscoring the importance of lipid removal when analyzing tissues for stable isotopes.
\end{abstract}

KEY WORDS: Stable isotopes $\cdot$ Northern fur seals $\cdot$ Feeding ecology $\cdot$ Foraging $\cdot$ Migration $\cdot$ Trophic dynamics

Present addresses:

*Ecology and Evolutionary Biology, University of California, 100 Shaffer Road, Santa Cruz, California 95060, USA.

E-mail: kurle@biology.ucsc.edu

${ }^{* *}$ Department of Biology, University of Central Florida, 4000

Central Florida Boulevard, Orlando, Florida 32816, USA

\section{INTRODUCTION}

Analysis of naturally occurring stable nitrogen and carbon isotope ratios $\left({ }^{15} \mathrm{~N} /{ }^{14} \mathrm{~N}\right.$ and ${ }^{13} \mathrm{C} /{ }^{12} \mathrm{C}$, respectively) is widely recognized as an important tool for 
making inferences about the feeding ecology of wild and captive animals (e.g. DeNiro \& Epstein 1978, 1981, Hobson et al. 1997, Burns et al. 1998, Kurle 1998, Kelly 2000, Kurle \& Worthy 2001). Predator tissue usually contains higher ratios of heavy to light nitrogen and carbon isotopes than prey tissue due to isotopic fractionation (Minagawa \& Wada 1984, Ambrose \& DeNiro 1986, Owens 1987, Schimel 1993, Michener \& Schell 1994, Gannes et al. 1997), and this progressive ${ }^{13} \mathrm{C}$ and ${ }^{15} \mathrm{~N}$ enrichment with trophic level lends itself to the analysis of food webs (e.g. DeNiro \& Epstein 1978, 1981, Kelly 2000). The trophic levels mentioned herein refer to 1 of the hierarchical strata of a food web characterized by organisms which are the same number of steps removed from the primary producers. The stepwise enrichment of ${ }^{15} \mathrm{~N}$ between prey and predator attributed to dietary fractionation is $\sim 3$ to $5 \%$ per trophic level (Rau et al. 1983, Minagawa \& Wada 1984, Wada et al. 1987, 1991, Fry 1988, Hobson \& Welch 1992, Hobson et al. 1994, 1996, Kurle 2002). The fractionation of carbon between trophic levels in marine vertebrates is very weak ( 0 to $1 \%$ ), thus limiting its use as a trophic indicator (Rau et al. 1983, Wada et al. 1987, Fry 1988, Hobson \& Welch 1992, France \& Peters 1997, Kelly 2000). However, variations in carbon isotope ratios reflect sources of primary productivity which, in turn, reflect foraging location, making it possible to track movement and migration patterns between isotopically distinct geographic regions (McConnaughey \& McRoy 1979, Nakamura et al. 1982, Rau et al. 1983, Hobson \& Welch 1992, Hobson 1993, Hobson et al. 1994, Smith et al. 1996, Minami \& Ogi 1997, Gannes et al. 1998, Schell et al. 1998, Burton \& Koch 1999, Cherel et al. 2000, Kurle \& Worthy 2001). When analyzing isotope ratios to obtain dietary data, it is important to consider the processes (or 'secondary fractionation effects') that govern the assimilation of nitrogen and carbon that can confound dietary analysis (Gaebler et al. 1966, Tieszen 1978, Tieszen et al. 1983, Macko et al. 1987, Owens 1987, Engel \& Macko 1993, Hobson 1993, Gannes et al. 1997, 1998, Focken \& Becker 1998). Secondary fractionation effects vary with tissue type not only due to differences in metabolic activity as mentioned below, but also because of differences in protein synthesis (Schoenheimer 1942, Welle 1999), and/or amino acid content (Lindstedt \& Prockop 1961, Gaebler et al. 1966, Macko et al. 1983, 1986, 1987 , Hare et al. 1991, Engel \& Macko 1993, Fantle et al. 1999). For instance, different amino acids make up various proteins and there are large variations in individual amino acid isotope ratios (Macko et al. 1987, Hare et al. 1991, Fantle et al. 1999) which can lead to isotope ratio differences between tissues. The degree to which these processes affect isotope ratios is poorly understood, which leads to complications when interpret- ing isotopic data as they relate to diet (see Kelly 2000). However, despite these difficulties, data indicate that analyzing a host of tissues from a particular subject can be useful for analyzing feeding ecology over time. For example, Hobson et al. (1996) showed fractionation factors for $\delta^{15} \mathrm{~N}$ between captive phocid seal tissues and their diet that were $+2.4 \%$ o (muscle, $\mathrm{n}=2$ ), $+2.7 \%$ o (kidney, $\mathrm{n}=1$ ),$+3.0 \%$ o (hair, $\mathrm{n}=10$ ), and $+3.1 \%$ (liver, $\mathrm{n}=2$ ). The mean $\delta^{15} \mathrm{~N}$ fractionation factors between captive northern fur seal red blood cells $(n=6)$, underfur $(\mathrm{n}=2)$, plasma $(\mathrm{n}=6)$ and their diet were $+4.1,+4.1$, and $+5.2 \%$, respectively (Kurle 2002 and unpubl. data). The seals in both cases were held on known diets for a considerable period of time, and these tissues showed minimal isotopic variation. Hildebrand et al. (1996) determined that stable isotope ratios from brown bear Ursus arctos fur that grew while the animals had access to spawning salmon were significantly enriched in ${ }^{15} \mathrm{~N}$ and ${ }^{13} \mathrm{C}$ over red blood cells that were collected before the annual return of spawning salmon, when the greater part of their diet contained isotopically lighter terrestrial plants. The results from captive seals on known diets suggesting low isotopic variability between some tissues, combined with the results from Hildebrand et al.'s (1996) study indicate that, despite possible complications introduced by the previously mentioned secondary fractionation effects, analyzing a suite of tissues from a group of wild animals can be useful in studying foraging ecology over time.

Turnover of stable isotopes varies according to protein metabolic rate, so the analysis of multiple tissue types from 1 individual allows for a more thorough approach to feeding ecology studies by providing trophic level and feeding location data over a range of timescales (Tieszen et al. 1983, Schell et al. 1989, Hobson \& Clark 1992, Hobson \& Welch 1992, Hildebrand et al. 1996, Hobson et al. 1996, 1997, Burton \& Koch 1999, Kelly 2000). Tissues with high rates of biochemical turnover give dietary information assimilated from recent feeding bouts, while slower turnover tissues indicate feeding data from more remote periods of time. Protein turnover rates, presented as percent protein synthesis per day from humans and other large mammals (summarized in Welle 1999), approximate the different speeds at which protein synthesis occurs in different tissues. Kidney (20 to $42 \% \mathrm{~d}^{-1}$ ) and liver (15 to $54 \% \mathrm{~d}^{-1}$ ) have high protein turnover, with average protein half-lives of $\sim 1.9$ to $6.7 \mathrm{~d}$. Brain $\left(8 \% \mathrm{~d}^{-1}\right)$ and adipose tissue $\left(5 \% \mathrm{~d}^{-1}\right)$ have a slower turnover, with average protein half-lives of $\sim 12.5$ and $\sim 20 \mathrm{~d}$, respectively. Skeletal muscle $\left(1.2\right.$ to $\left.8 \% \mathrm{~d}^{-1}\right)$ has an even slower turnover, with an average protein half-life of $\sim 12.5$ to $83.3 \mathrm{~d}$.

Protein turnover rates are thought to influence isotopic turnover rates (S. Welle, University of Rochester 
Medical Center, pers. comm.) which, in turn, reflect the time period of isotopic incorporation (see also Tieszen et al. 1983, Hobson \& Clark 1992). Data indicate that near-complete integration of diet into a particular tissue occurs after approximately 2 to 3 isotope half-lives (Tieszen et al. 1983, Hobson \& Clark 1992, Hobson 1993, Hildebrand et al. 1996). The half-lives for nitrogen and carbon stable isotopes refer to the time it takes for the respective isotope ratios measured in a specific tissue to shift from those derived from one particular diet to another, and they vary depending upon the metabolic rate of the tissue in question (see Tieszen et al. 1983, Hobson \& Clark 1992). Therefore, isotope ratios reflect nutrients incorporated into a particular tissue starting at a time period previous to collection that is roughly 2 to 3 times longer than its isotopic half-life. Metabolically inactive tissues such as feathers and fur reflect isotopes incorporated during their growth (Schell et al. 1989, Hobson \& Clark 1992, Gannes et al. 1998). For this study, we analyzed fur, liver, kidney, brain, muscle, and blubber tissues from juvenile male fur seals. They molt their fur every year, beginning in late July/early August and continuing for 4 to 5 mo (Scheffer 1962, Scheffer \& Johnson 1963). Fur is not completely replaced every year, with an estimated $25 \%$ retention of old-generation guard hairs thought to persist following the molt (Scheffer \& Johnson 1963). Thus, fur sampled during the summer reflected isotopes incorporated during the previous year's molt, and, to a lesser extent, during earlier molts. Liver and kidney isotope ratios provided short-term trophic level information, and brain, blubber, and muscle tissues provided intermediate dietary data. Therefore, comparison of isotope ratios from different tissues provided trophic level information, feeding location, and migration data over a range of timescales.

It has been shown that stable isotope ratios of organisms in marine and terrestrial systems vary geographically, allowing researchers to track animal movement by analyzing animal isotope values (see review by Hobson 1999). Carbon isotope ratios of organisms in a marine trophic system are influenced by the phytoplankton at the base of the food web which, in turn, are influenced by (among other things) phytoplankton size, geometry, and growth rate (Laws et al. 1995, Pancost et al. 1997, Popp et al. 1998), the occurrence of phytoplankton blooms (Nakatsuka et al. 1992, Gervais \& Riebesell 2001), the amount of primary productivity (Descolas-Gros \& Fontugne 1990, Laws et al. 1995, Bidigare et al. 1997, Schell 2000), and $\mathrm{CO}_{2}$ concentration and $\mathrm{CO}_{2}$ uptake mechanisms (Burkhardt et al. 1999, Tortell et al. 2000). In addition, nitrogen and carbon isotope ratios show predictable variation with latitude and longitude. Nitrogen isotope ratios exhibit an increasing gradient with longitude from west to east in the Bering Sea that is probably due to differential nutrient conditions, with higher nitrogenous nutrients leading to lower zooplankton $\delta^{15} \mathrm{~N}$ values (see Schell et al. 1998). Organisms from middle latitudes generally have $\delta^{13} \mathrm{C}$ values that are higher than those sampled in high latitudes (Rau et al. 1982, 1989, Dunton et al. 1989, Hobson et al. 1997, Burton \& Koch 1999). This is thought to be due to an increase in dissolved $\mathrm{CO}_{2}$ concentration with decreasing temperature and with increasing latitude (Rau et al. 1989, 1992, Gericke \& Fry 1994, Burton \& Koch 1999) combined with the differential uptake of ${ }^{12} \mathrm{C}$ and ${ }^{13} \mathrm{C}$ caused by the biological and environmental differences mentioned above. There is also a demonstrated increasing $\delta^{13} \mathrm{C}$ gradient with longitude from east to west across the Alaskan and Canadian Beaufort Seas, the Chukchi Sea, and the northern Bering Sea (Dunton 1985, Saupe et al. 1989). Therefore, coupling-known spatial variation of carbon isotopes with tissue-specific temporal variation allows researchers to track animal movements (Chamberlain et al. 1997, Hobson \& Schell 1998 Burton \& Koch 1999, Hobson 1999, Cherel et al. 2000).

Juvenile male northern fur seals are thought to spend much of the year offshore in the North Pacific Ocean (Bigg 1986, 1990). The majority of fur seals move to the Pribilof Islands region in the eastern Bering Sea by July, and, during an 80 d breeding season, juvenile males alternate between time spent onshore fasting (an average of 3.1 visits ashore, each lasting an average of $11.6 \mathrm{~d}$ ), and time spent at sea feeding (an average of 8.4 d per trip) (Baker et al. 1994, Gentry 1998). It is difficult to estimate trophic position and location of juvenile males, especially during their migration. Their haul-out behavior during the summer months makes them ideal candidates for multiple tissue sampling, stable isotope analysis, and subsequent estimations of trophic level and foraging location.

The primary objective of this study was to analyze nitrogen and carbon isotope ratios in a variety of tissues from a migratory, marine carnivore in order to make inferences about trophic and geographic aspects of its feeding ecology over time. We tested for isotopic differences among tissue types, and between juvenile male fur seals sampled on St. Paul and St. George Islands. We included analysis of tissues from 2 nulliparous (having never borne offspring) and 2 postparturient (having borne offspring) females for comparison.

\section{MATERIALS AND METHODS}

Sample collection. Juvenile male fur seals were sampled in July and August 1997 from 8 different haul-out sites on St. Paul and St. George Islands, 
Alaska, in the eastern Bering Sea (Fig. 1). Tissue samples from $3 \mathrm{yr}$ old male fur seals $(\mathrm{n}=70$; age was judged by counting growth layers on a canine tooth extracted from each individual), nulliparous females $(n=2)$, and post-parturient females $(n=1)$ were collected in late July and early August 1997 from individuals killed in Aleut subsistence harvests. Juvenile males are targeted in the harvests, and were therefore the predominate sex available for sampling. One additional post-parturient female that died giving birth was sampled opportunistically. Samples of fur, skin, brain, kidney, liver, blubber, and skeletal muscle from the upper back were collected, frozen within 2 to $3 \mathrm{~h}$ of the seal's death, and transported to the laboratory for later analysis.

Sample preparation and analysis. As a pelt, all fur was washed thoroughly with soap and distilled water; sub-samples that included both under-fur and guard hairs were then cut at random. Sub-samples of all remaining tissues were taken from the centers of the larger samples to avoid contamination, rinsed with distilled water, and freeze-dried for $24 \mathrm{~h}$. Lipids were extracted from all samples (except fur and a duplicate set of blubber samples) with petroleum ether in a Soxhlet extractor for $24 \mathrm{~h}$ (as recommended by Dobush et al. 1985), and then dried at $60^{\circ} \mathrm{C}$ for $24 \mathrm{~h}$ to evaporate any remaining solvent. The non-lipid-extracted (NLE) blubber samples were sub-sampled and uniformly mashed. Remaining tissues were ground to powder by hand. Aliquots (0.9 to $1.5 \mathrm{mg}$ ) of the

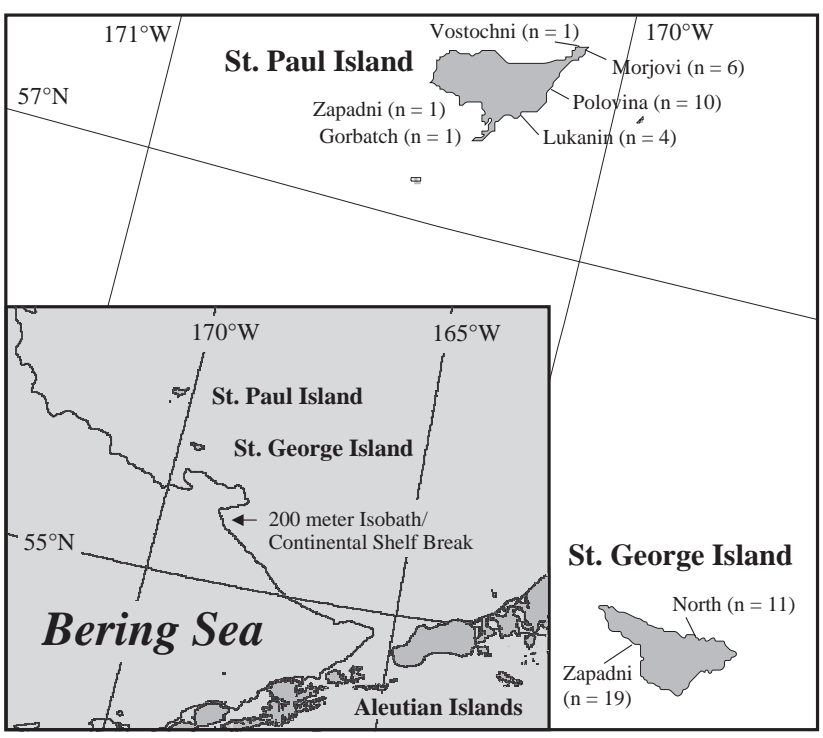

Fig. 1. Study areas in the Bering Sea on St. Paul and St. George Islands, Alaska; individual haul-out sites where tissue collection occurred are identified along with sample sizes from each site. The $200 \mathrm{~m}$ isobath is marked for reference samples were sealed into $5 \times 9 \mathrm{~mm}$ tin capsules and analyzed using a Carlo Erba NA 1500 CHN combustion analyzer interfaced to a Finnigan Delta C mass spectrometer at the Stable Isotope/Soil Biology Laboratory, University of Georgia Institute of Ecology, Athens, GA. The average precision for these data was $0.09 \%$ for nitrogen and $0.13 \%$ for carbon.

The natural isotopic abundance of ${ }^{15} \mathrm{~N}$ or ${ }^{13} \mathrm{C}$ in a sample is expressed in delta notation:

$$
\delta X(\%)=\frac{R_{\text {sample }}-R_{\text {standard }}}{R_{\text {standard }}} \times 1000
$$

where $\delta X$ is the parts-per-thousand (or 'per mil') difference in isotopic composition between the sample and the standard, and $R_{\text {sample }}$ and $R_{\text {standard }}$ are the heavyto-light isotope ratios of the sample and standard, respectively (i.e. ${ }^{15} \mathrm{~N} /{ }^{14} \mathrm{~N}$ and ${ }^{13} \mathrm{C} /{ }^{12} \mathrm{C}$ ) (DeNiro \& Epstein 1981, Owens 1987, Ehleringer \& Rundel 1989, Boutton 1991).

General inferences about fur seal trophic levels were made by comparing stable isotope ratios from the fur seal tissue samples with those from prey taken during the same time in the Bering Sea (Kurle \& Worthy 2001), and from prey taken between 1993 and 1996 from the inner shelf and shelf break in the Bering Sea, and near Kodiak Island and the Alaska Peninsula in the western Gulf of Alaska (Hobson et al. 1997, Hirons et al. 1998).

Statistical treatment of isotope ratio data. All data collected from juvenile male fur seals were judged to be sampled from normal distributions using frequency distribution $z$-score histograms. Analysis of variance (ANOVA) tests were used to determine equality of tissues sampled from each island, and to determine equality of tissues collected from different haul-out sites on St. Paul Island. Unpaired $t$-tests were used to determine differences in stable nitrogen and carbon isotope ratios between St. Paul and St. George Islands for each tissue type, and to determine equality of tissues collected from 2 haul-out sites on St. George Island (StatView for Windows: Abacus Concepts, Berkeley, CA, 1992-1996). Significance was tested at the $\alpha=0.05$ level. Agglomerative hierarchical clustering was used to determine tissue groupings based on tissue $\delta^{15} \mathrm{~N}$ and $\delta^{13} \mathrm{C}$ values for each island using squared Euclidean distance as the measure of similarity between tissue types and an average linkage type to compare cluster distances. Logical spatial breaks between clusters were determined from output dendograms and used to group tissue types (S-PLUS 2000 Professional Release 2: MathSoft, Seattle, WA, 1988-1999). Due to small sample sizes, the samples from females were not analyzed statistically, but are included for comparison. 


\section{RESULTS}

There were no significant differences in mean $\delta^{15} \mathrm{~N}$ and $\delta^{13} \mathrm{C}$ values between haul-out sites for any tissues on either island (St. Paul Island, all $\mathrm{p}>0.05$, ANOVAs, St. George Island, all $\mathrm{p}>0.05$, Student's $t$-tests), so they were pooled as representative of their respective islands. There were significant differences in $\delta^{15} \mathrm{~N}$ values between some tissue types (St. Paul and St. George Islands, p < 0.001 ; ANOVA). Mean $\delta^{15} \mathrm{~N}$ of all tissues collected on both islands ranked from lowest to highest as follows (St. Paul Island values listed first, St. George Island second): fur $(14.9 \%$, $14.8 \%$ o $<$ muscle $(15.1 \%$ o, $15.6 \%$ o < NLE blubber $(15.8 \%$, $16.0 \%$ o $<$ liver $(16.2 \%$, $16.0 \%$ o $<$ kidney $(16.4 \%$, $16.3 \%$ o $)<$ brain $(17.0 \%$, $16.9 \%$ o) < lipid-extracted (LE) blubber $(17.1 \%$, $17.1 \%$ ) (Table 1, Fig. 2). Mean $\delta^{15} \mathrm{~N}$ values were the same for each given tissue between islands (all p > 0.05; $t$-tests), with the exception of muscle, where samples collected from St. George were an average of $0.5 \%$ higher than those collected from St. Paul ( $\mathrm{p}=0.03 ; t$-test). Mean $\delta^{15} \mathrm{~N}$ values for NLE blubber were significantly lower than LE blubber by $1.3 \%$ o $(\mathrm{p}<0.001$; $t$-test). Fur from both islands was significantly depleted in ${ }^{13} \mathrm{~N}$ (all $\mathrm{p}<0.05$; Fisher's protected least-significant difference, PLSD) compared to other tissues, except for muscle collected from St. Paul Island which was the same ( $p=$ 0.558 ; $t$-test). Agglomerative hierarchical clustering was performed on the mean $\delta^{15} \mathrm{~N}$ values from all tissues except for NLE blubber, which was excluded due to methodological differences in its preparation. Clustering detected 3 major tissue groupings at the 0.7 level for St. Paul Island: (1) fur and muscle, (2) brain and LE blubber, (3) kidney and liver; 4 major tissue groupings were identified at the 0.6 level for St. George Island: (1) fur, (2) muscle, (3) brain and LE blubber, (4) kidney and liver.

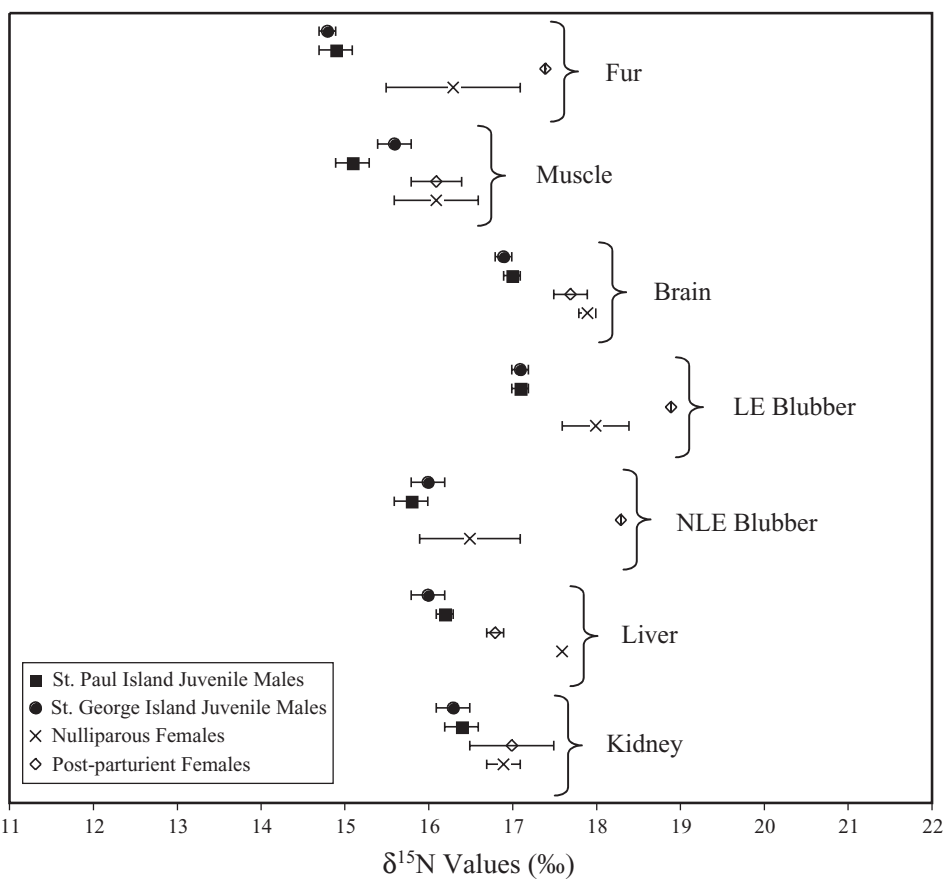

Fig. 2. Callorhinus ursinus. Mean $( \pm \mathrm{SE})$ stable nitrogen isotope ratios of multiple tissues from northern fur seals from the Pribilof Islands, Alaska. Sample sizes are given in Tables 1 \& 2. LE: lipid-extracted; NLE: non-lipid-extracted

There were significant differences in $\delta^{13} \mathrm{C}$ between some tissue types (tissues from St. Paul and St. George Islands were tested separately, and for both $\mathrm{p}<0.001$; ANOVA). Mean $\delta^{13} \mathrm{C}$ values of all tissues collected on St. Paul Island ranked from lowest to highest as follows: NLE blubber $(-24.7 \%$ o) < kidney $(-18.5 \%$ o $)<$ liver $(-18.4 \%)<$ brain, LE blubber, muscle $(-18.1 \%)<$ fur $(-17.5 \%)$. Mean ${ }^{13} \mathrm{C}$ values of all tissues collected on St. George Island ranked from lowest to highest as follows: NLE blubber $(-24.6 \%)<$ LE blubber $(-19.7 \%$ o $)<$ brain $(-18.4 \%)<$ kidney, liver $(-18.2 \%)<$ muscle $(-18.0 \%)<$ fur $\left(-17.9 \%\right.$ ) (Table 1, Fig. 3). Mean $\delta^{13} \mathrm{C}$ for muscle was the same between islands $(\mathrm{p}=0.557$; $t$-tests), whereas $\delta^{13} \mathrm{C}$ for liver and kidney were 0.2 and

Table 1. Callorhinus ursinus. Mean $( \pm \mathrm{SE}) \delta^{15} \mathrm{~N}$ and $\delta^{13} \mathrm{C}(\%)$ in tissues from juvenile males collected in July-August 1997 from the Pribilof Islands, Alaska. Values in parentheses: no. of samples; LE: lipid-extracted; NLE: non-lipid-extracted

\begin{tabular}{|lcccc}
\hline Tissue type & \multicolumn{2}{c}{$\delta^{15} \mathrm{~N}$ values } & \multicolumn{2}{c}{$\delta^{13} \mathrm{C}$ values } \\
& St. Paul Island & St. George Island & St. Paul Island & St. George Island \\
\hline Fur & $14.9 \pm 0.2(39)$ & $14.8 \pm 0.1(28)$ & $-17.5 \pm 0.1(39)$ & $-17.8 \pm 0.1(27)$ \\
Muscle & $15.1 \pm 0.2(38)$ & $15.6 \pm 0.2(30)$ & $-18.1 \pm 0.1(37)$ & $-18.0 \pm 0.1(30)$ \\
Brain & $17.0 \pm 0.1(39)$ & $16.9 \pm 0.1(29)$ & $-18.1 \pm 0.1(39)$ & $-18.4 \pm 0.1(29)$ \\
LE Blubber & $17.1 \pm 0.1(36)$ & $17.1 \pm 0.1(30)$ & $-18.1 \pm 0.2(36)$ & $-19.7 \pm 0.4(30)$ \\
NLE Blubber & $15.8 \pm 0.2(31)$ & $16.0 \pm 0.2(17)$ & $-24.7 \pm 0.1(34)$ & $-24.6 \pm 0.1(19)$ \\
Liver & $16.2 \pm 0.1(40)$ & $16.0 \pm 0.2(30)$ & $-18.4 \pm 0.1(40)$ & $-18.2 \pm 0.1(30)$ \\
Kidney & $16.4 \pm 0.2(37)$ & $16.3 \pm 0.2(26)$ & $-18.5 \pm 0.1(37)$ & $-18.2 \pm 0.1(28)$ \\
\hline
\end{tabular}




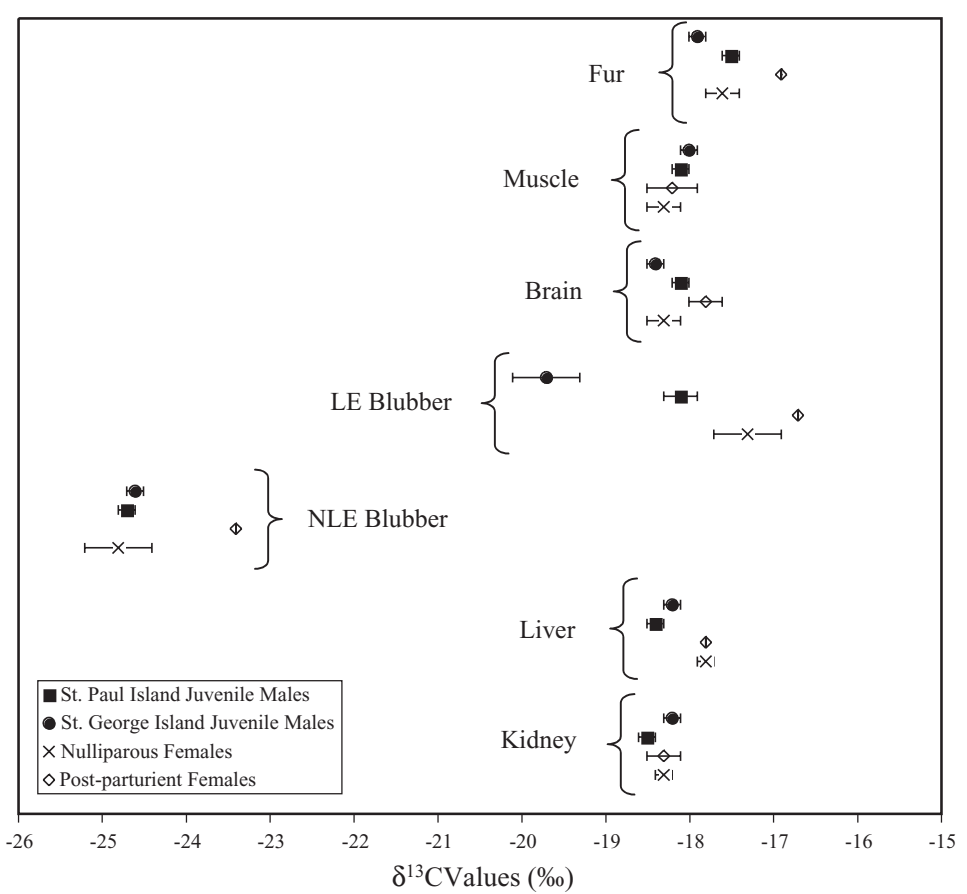

Fig. 3. Callorhinus ursinus. Mean $( \pm \mathrm{SE})$ stable carbon isotope ratios of multiple tissues from northern fur seals from the Pribilof Islands, Alaska. Sample sizes are given in Tables 1 \& 2

$0.3 \%$ higher, respectively, on St. George Island $(\mathrm{p}=$ 0.018 and 0.023 , respectively; $t$-tests), and $\delta^{13} \mathrm{C}$ for brain, fur and LE blubber were $0.3,0.4$, and $1.6 \%$ higher, respectively, on St. Paul Island $(p=0.001$, brain; $_{\text {; }}$ and $\mathrm{p}<0.001$, fur and LE blubber; $t$-tests). For samples from both islands, NLE blubber was significantly depleted in ${ }^{13} \mathrm{C}$ by 4.9 to $6.6 \%$ compared to LE blubber ( $p<0.001 ; t$-test). $\delta^{13} \mathrm{C}$ from brain, LE blubber, and muscle were the same for seals from St. Paul Island $(p=0.974$; ANOVA), but not for seals sampled on St. George Island ( $<0.001$; ANOVA). Agglomerative hierarchical clustering was performed on the mean $\delta^{13} \mathrm{C}$ values from all tissues except for NLE blubber, which was excluded due to methodological differences in its preparation. Three discrete tissue groupings were identified by cluster analysis at the 0.4 level for St. Paul Island: (1) fur, (2) muscle, brain and LE blubber, (3) kidney and liver; 4 tissue groupings were identified at the 0.4 level for St. George Island: (1) fur and muscle, (2) LE blubber, (3) brain, (4) kidney and liver.

Although sample sizes were not large enough to allow statistical comparison, the tissues from females on St. Paul Island provided some interesting results (Table 2, Figs. $2 \& 3$ ). All females, regardless of reproductive status, had higher mean $\delta^{15} \mathrm{~N}$ values (16.1 to $18.9 \%$ ) than juvenile males (14.8 to $17.1 \%$ ) for all tissues. Post-parturient females had higher mean $\delta^{15} \mathrm{~N}$ values than nulliparous females for LE blubber, NLE blubber, and fur. Nulliparous females had higher mean $\delta^{15} \mathrm{~N}$ values than post-parturient females for liver. The remaining tissues (muscle, kidney, and brain) were not different between post-parturient and nulliparous females. $\delta^{13} \mathrm{C}$ values were the same or nearly so for nulliparous females and juvenile males from St. Paul Island for all tissues except liver and LE blubber. $\delta^{13} \mathrm{C}$ values of kidney and muscle in post-parturient females were the same or very close to those of St. Paul Island juvenile males and nulliparous females, but all other tissues were different.

\section{DISCUSSION}

A change in diet and feeding location over time appears to have occurred in northern fur seal males, as indicated by the differences in isotope ratios measured in a variety of tissues. Hierarchical analysis of mean $\delta^{15} \mathrm{~N}$ and $\delta^{13} \mathrm{C}$ values from all the tissues placed them into groups that coincided with similarities in protein turnover rates. Variability in the isotope ratios may be partially attributable to other effects such as differ-

Table 2. Callorhinus ursinus. Mean $( \pm \mathrm{SE}) \delta^{15} \mathrm{~N}$ and $\delta^{13} \mathrm{C}(\%)$ from nulliparous and post-parturient tissues of females collected opportunistically in July-August 1997 from St. Paul Island, Alaska. Values in parentheses: no. of samples

\begin{tabular}{|c|c|c|c|c|}
\hline \multirow{2}{*}{ Tissue type } & \multicolumn{2}{|c|}{$\delta^{15} \mathrm{~N}$ values } & \multicolumn{2}{|c|}{$\delta^{13} \mathrm{C}$ values } \\
\hline & Nulliparous & Post-parturient & Nulliparous & Post-parturient \\
\hline Fur & $16.3 \pm 0.8(2)$ & $17.4(1)$ & $-17.6 \pm 0.2(2)$ & $-16.9(1)$ \\
\hline Muscle & $16.1 \pm 0.5$ & $16.1 \pm 0.3(2)$ & $-18.3 \pm 0.2(2)$ & $-18.2 \pm 0.3(2)$ \\
\hline Brain & $17.9 \pm 0.1(2)$ & $17.7 \pm 0.2(2)$ & $-18.3 \pm 0.2(2)$ & $-17.8 \pm 0.2(2)$ \\
\hline LE blubber & $18.0 \pm 0.4$ & 18.9 (1) & $-17.3 \pm 0.4$ & $-16.7(1)$ \\
\hline NLE blubber & $16.5 \pm 0.6$ & $18.3(1)$ & $-24.8 \pm 0.4(2)$ & $-23.4(1)$ \\
\hline Liver & $17.6 \pm 0.0$ & $16.8 \pm 0.1(2)$ & $-17.8 \pm 0.1(2)$ & $-17.8 \pm 0.0(2)$ \\
\hline Kidney & $16.9 \pm 0.2(2)$ & $17.0 \pm 0.5(2)$ & $-18.3 \pm 0.1(2)$ & $-18.3 \pm 0.2(2)$ \\
\hline
\end{tabular}


ences in isotope assimilation in the individual tissue types. Isotopic fractionation between diet and predator tissue varies considerably among individual amino acids (Macko et al. 1987, Hare et al. 1991, Fantle et al. 1999). Therefore, the most common proteins in a specific tissue, and thus proportions of different amino acids present, may vary at a rate significant enough to directly influence a particular tissue's isotope ratio (Hare et al. 1991). For example, while red blood cells and fur from captive northern fur seals held on a known diet exhibited $\delta^{15} \mathrm{~N}$ fractionation values of $+4.1 \%$ (see 'Introduction') between their diet and their fur and red blood cells, fur seal plasma and serum had a fractionation value that was $1.1 \%$ greater $(+5.2 \%$ : Kurle 2002$)$. This was attributable largely to a difference in protein content and, thus, amino acids between the tissues. Finally, another source of variability may be introduced by differences in the habitats utilized by the prey. Prey feeding in different locations and being eaten by fur seals could exhibit differences in isotope ratios that are influenced by geography in addition to trophic level. While it is important to consider the influence of secondary fractionation effects on the isotopic variation between tissues, the comparison of a suite of tissues such as those analyzed in this study is still useful for the indication of trophic and migratory changes over a rough time period.

Following their initial pup molts at $2 \mathrm{wk}$ and at $2 \mathrm{mo}$ of age, northern fur seals molt annually, so isotope values from fur should reflect the diet incorporated primarily during the most recent molt (Schell et al. 1989, Gannes et al. 1998), with an unknown, smaller percentage of fur reflecting the diet incorporated during previous molts (Scheffer \& Johnson 1963). The mean mid-date of molting for 2 yr old male fur seals is September 14, with the molt lasting from July to November (Scheffer \& Johnson 1963). Therefore, the $\delta^{15} \mathrm{~N}$ of fur sampled in summer 1997 from $3 \mathrm{yr}$ olds should largely relate to feeding ecology from approximately July to November 1996, when the sampled males were $\sim 2 \mathrm{yr}$ old, and some fur may reflect feeding ecology from their pup molt and their age 1 yr molt. Generally, 1 and 2 yr old males remain offshore in the eastern North Pacific with only a few coming into the Pribilof Islands region (Bigg 1990), and so fur grown during this period will reflect time spent in the eastern North Pacific. Fur samples from both islands were significantly depleted in ${ }^{15} \mathrm{~N}$ compared to other tissues (except for muscle collected from St. Paul Island males). Thus, juvenile male fur seals appear to have been feeding at a somewhat lower trophic level compared to any other time in the subsequent year. This supports previous findings on harp seals that suggest that they also feed at higher trophic levels with increasing age (Lawson \& Hobson 2000). Availability of and/or access to prey in the east- ern North Pacific during late summer-early fall (at the time of their molting) may have been significantly different from that during other times of the year or when juvenile males were near the Pribilof Islands. As our data suggest that juvenile males feed at higher trophic levels with increasing age, it is possible that 1 and $2 \mathrm{yr}$ old males were at a physiological and/or behavioral disadvantage (e.g. diving capabilities were not as strong) compared to $3 \mathrm{yr}$ old males. This disadvantage could have prevented them from foraging for higher trophic level prey (see Horning \& Trillmich 1997).

Fur from males on St. Paul Island had a slightly higher mean $\delta^{13} \mathrm{C}$ value than fur from males on St. George Island, indicating that they may have been feeding in separate areas of the eastern North Pacific during that time. Slight, but distinct, differences in primary productivity, or varying latitude or longitude between feeding areas, may have contributed to the dissimilarity. For example, seals from St. George Island may have been feeding in higher-latitude waters of the North Pacific than those from St. Paul Island. However, the difference is so minor that it may not warrant such an interpretation and may be coincidental. Finally, future studies utilizing fur for isotopic analysis should consider separating guard hair and underfur and analyzing each portion independently in the event that they grow or are replaced at different rates.

Isotope ratios from muscle tissue should illustrate nitrogen and carbon assimilated up to many months previous to collection, as muscle has a slower rate of fractional protein synthesis per day than brain and fat tissue (Waterlow et al. 1978, Welle 1999), and a slower rate of carbon turnover than fat tissue (brain isotopic turnover data unavailable: Tieszen et al. 1983). This would reflect a time period beginning in late fall 1996, which would correlate with early, mid-, and late migration, when juvenile males are thought to be primarily in the eastern North Pacific, and then the Gulf of Alaska, and finally the eastern Bering Sea (Bigg 1990). The start of isotopic incorporation in muscle tissue probably overlaps with the end of the time suggested by the fur samples. Mean $\delta^{15} \mathrm{~N}$ in muscle tissue was higher for samples collected on St. George Island than for those collected on St. Paul, suggesting a slight difference in trophic level between the 2 groups. This was the only indication of a trophic level difference for the juvenile males between the 2 islands. Further, the $\delta^{15} \mathrm{~N}$ values were the same for both fur and muscle for individuals from St. Paul and only slightly higher for muscle over fur for those from St. George, suggesting there was little change in trophic level between the time periods indicated by the protein turnovers in each tissue.

Brain and blubber have slower protein turnover rates than kidney and liver (Welle 1999), so their isotope ratios should indicate diet that was incorporated 
beginning several months prior to collection. In spring, juvenile males are thought to move out of the eastern North Pacific and into the Gulf of Alaska, then into western Alaska and the Aleutian Islands in late springearly summer, and finally into the eastern Bering Sea by June-July (Bigg 1990). Brain and LE blubber had the highest $\delta^{15} \mathrm{~N}$ ratios, suggesting that they were feeding at their highest trophic level during this time. Additionally, it has been demonstrated that $\delta^{15} \mathrm{~N}$ values of particulate organic nitrogen increase as one moves from the Bering Sea south through the Pacific Ocean (Saino \& Hattori 1987). This is likely to be reflected at higher trophic levels (Hobson et al. 1997, Burton et al. 2001), and may have contributed to the higher $\delta^{15} \mathrm{~N}$ values in the brain and blubber tissues.

Lack of differences in $\delta^{13} \mathrm{C}$ for muscle, LE blubber, and brain tissue from seals on St. Paul Island suggests that they occupied similar habitat areas during early, mid-, and late migration. Observed differences in $\delta^{13} \mathrm{C}$ for the same tissues in males from St. George Island suggest that these males may have fed in different habitats throughout their migration. Muscle $\delta^{13} \mathrm{C}$ ratios were the same between islands, suggesting that, at the time in their migration to the Pribilof Islands indicated by muscle protein turnover times, all juvenile males were feeding in the same waters of the eastern North Pacific. Lower LE blubber and brain $\delta^{13} \mathrm{C}$ values from St. George Island suggested they may have fed in different areas during mid- and late migration than the males from St. Paul Island.

Kidney and liver tissues are related to recently consumed diet due to their rapid and total protein turnover (Schoenheimer 1942, Thompson \& Ballou 1956, Waterlow et al. 1978, Tieszen et al. 1983, de la Higuera et al. 1999). Mean $\delta^{15} \mathrm{~N}$ and $\delta^{13} \mathrm{C}$ in the kidney and liver should reflect foraging location and prey eaten by fur seals during the previous month or less. Thus, liver and kidney tissues from seals killed in the subsistence harvests in late July through mid-August reflect prey consumption during the breeding season from late June to mid-July. Most juvenile male fur seals arrive at the Pribilof Islands by early July. From their arrival until September, juvenile males spend most of their time at sea foraging, with the average males making three $10 \mathrm{~d}$ visits to their respective islands (Gentry et al. 1979). Foraging trips taken by satellite-tagged juvenile males from St. Paul Island in summer/fall 1999 included movement of $680 \mathrm{~km}$ to the north, $544 \mathrm{~km}$ east to Bristol Bay, and $1015 \mathrm{~km}$ southwest to the Aleutian Islands (National Marine Mammal Laboratory unpubl. data), indicating that some of their foraging may occur in and around the Bering Sea at great distances from the Pribilof Islands. Mean $\delta^{15} \mathrm{~N}$ values for kidney and liver sampled from both islands were the same $(p=0.395$; ANOVA $)$, indicating that, regard- less of feeding location, juvenile males from St. Paul and St. George Islands were feeding at the same trophic level.

Data derived from stomach contents and fecal analyses indicate that the primary dietary components of post-parturient female and a small number of juvenile male fur seals feeding off the Pribilof Islands are juvenile and small-sized fishes and squid (Sinclair et al. 1994, 1996, Antonelis et al. 1997). Prey parts found in scats thought to be from adult females indicate that the most common prey types for females from both islands were 0 to 2 yr old pollock Theragra chalcogramma and small squid, with St. George Island scats containing $55.2 \%$ squid to $25 \% 0$ to 2 yr old pollock, and St. Paul Island scats containing $7 \%$ squid to $70.6 \% 0$ to $2 \mathrm{yr}$ old pollock (Antonelis et al. 1997). Other prey such as older pollock ( 3 to $5 \mathrm{yr}$ old), Pacific sand lance Ammodytes hexapterus, and northern smoothtongue Leuroglossus schmidti also occurred, but with less frequency (Sinclair et al. 1994, Antonelis et al. 1997).

$\delta^{15} \mathrm{~N}$ for a particular tissue is a composite ratio for a diet that is probably composed of a variety of species. Specific prey items may fall close to a particular ratio, but that does not guarantee that a particular prey item is actually included within an animal's diet, and delineation of exact prey for northern fur seals is impractical. However, using an approximate $3 \%$ fractionation value between fur seal kidney and liver tissue and their prey (Hobson et al. 1996), the data indicated that 1 to 2 yr old pollock $\left(\delta^{15} \mathrm{~N}=12.7 \%\right.$ ) and medium-sized Pacific herring Clupea pallasii $\left(\delta^{15} \mathrm{~N}\right.$ value $=13.5 \%$ ) from the Bering Sea were probably a part of the fur seals' diet. $\delta^{15} \mathrm{~N}$ values for 0 -age pollock $\left(\delta^{15} \mathrm{~N}=10.8 \%\right.$ ) and squid $\left(\delta^{15} \mathrm{~N}=11.1\right.$ to $11.4 \%$ ) are too low for these to be included. However, isotope values for a combination diet of older pollock ( $\delta^{15} \mathrm{~N}$ values 15.2 to $16.3 \%$ ) and 0 -age pollock and squid would sum up to an isotopic average that would fall within the range of prey suggested by the fur seals' liver and kidney $\delta^{15} \mathrm{~N}$ values (all prey values from Kurle \& Worthy 2001).

Liver and kidney tissues were slightly more enriched in ${ }^{13} \mathrm{C}$ for individuals sampled on St. George Island than for those from St. Paul Island. The difference in $\delta^{13} \mathrm{C}$ between fur seals from the 2 islands supports the previous hypothesis that individuals from each island travel to different locations to feed (Antonelis et al. 1997). $\delta^{13} \mathrm{C}$ from zooplankton in the Bering Sea show variation with location on spatial scales easily traveled by juvenile males on feeding trips from the Pribilof Islands (Schell et al. 1998). For example, zooplankton sampled in the Bering Sea to the east of the Pribilof Islands generally have $\delta^{13} \mathrm{C}$ values as much as $4 \%$ lower (depending on the species) than zooplankton from west of the islands. There is also evidence that fur seal prey species from the inner continental shelf of 
the Bering Sea (east of the Pribilof Islands) consistently have slightly lower $\delta^{13} \mathrm{C}$ values than the same species along the shelf break (west of the Pribilof Islands) (Hirons et al. 1998, Schell et al. 1998). These observations are compatible with a higher primary productivity along the Bering Sea shelf edge (Springer et al. 1996) and a possible correlation between higher primary productivity and higher $\delta^{13} \mathrm{C}$ (Descolas-Gros \& Fontugne 1990, Laws et al. 1995, Bidigare et al. 1997, Schell 2000). Comparing our results with the isotopic maps created by Schell et al. (1998), the $\delta^{13} \mathrm{C}$ values from liver and kidney tissues suggest that, during the breeding season, juvenile males from St. George Island were feeding more to the west of the islands or at the continental shelf break $(200 \mathrm{~m}$ isobath: see Fig. 1), and those from St. Paul Island were feeding more to the east or on the continental shelf.

Despite small sample sizes, the isotope ratios from nulliparous and post-parturient females provided some interesting observations. One post-parturient female had $\delta^{15} \mathrm{~N}$ values from LE blubber, NLE blubber, and fur that were higher than for the 2 nulliparous females and the juvenile males. Isotopes were primarily incorporated into the fur during the previous fall, when mature females were on or around the Pribilof Islands and immature fur seals were in the eastern North Pacific. Adult females may have had access to higher trophic level prey or their fur may have become ${ }^{15} \mathrm{~N}$-enriched due to the nutritional stress of the fasting-feeding cycle and lactation during the breeding season (see Kurle \& Worthy 2001). It appears that nulliparous and postparturient females were feeding at higher trophic levels than juvenile males at all times throughout the year, as female $\delta^{15} \mathrm{~N}$ values were uniformly higher for all tissues. This is consistent with previous results reported for isotope analysis of northern fur seal skin from juvenile males and parturient females (Kurle \& Worthy 2001). Finally, isotopic variation such as that seen for zooplankton by Schell et al. (1998) could have accounted for some of the isotopic differences in the fur seals. Feeding in different locations around the Pribilof Islands could have contributed to both the higher overall $\delta^{15} \mathrm{~N}$ values for the females and the higher levels for the adult females over the nulliparous females.

The mean $\delta^{13} \mathrm{C}$ values from nulliparous females and juvenile males were the same for all tissues except the liver and LE blubber. Therefore, it appears that the immature females were in the same area or regime as juvenile males for much of the time between their molt in the summer-fall 1996 and when they were sampled in July-August 1997. This is consistent with previous conclusions reached by Kurle \& Worthy (2001). In contrast, post-parturient females had $\delta^{13} \mathrm{C}$ values that were the same as or very close to the nulliparous females only during times when both groups were on and around the Pribilof Islands (kidney and liver tissues) or thought to be in the North Pacific (muscle tissue). The isotope results may be coincidental and not directly related to fur seal foraging location; however, previous findings indicating specific times when juvenile males, immature females, and adult females do and do not overlap in their habitat usage (Bigg 1990) are supported by our data.

Previous studies have stressed that analyzing tissues with intact lipids leads to significantly lower $\delta^{13} \mathrm{C}$ ratios (see Kelly 2000), but possible effects of lipid loads on $\delta^{15} \mathrm{~N}$ values have not been directly addressed in the literature. Half of each individual fat sample collected in this study was lipid-extracted, and half was left intact. The NLE blubber was significantly depleted in both ${ }^{15} \mathrm{~N}$ and ${ }^{13} \mathrm{C}$ compared to the LE blubber. Lipids are made up of mostly carbon, hydrogen, and oxygen, with little nitrogen except what is found in the proteinaceous material in the cell walls and lipo-protein membranes (Lehninger 1982). When lipids are extracted, the cellular components left behind are mostly protein (Dobush et al. 1985). Therefore, NLE blubber contained a higher ratio of lipid to proteinaceous material, causing it to have lower $\delta^{15} \mathrm{~N}$ values than the blubber with its lipid content removed. $\delta^{15} \mathrm{~N}$ might then be a function of the ratio of protein to lipid per unit of tissue. As petroleum ether removes very little non-lipid material in the extraction process (Dobush et al. 1985), it is unlikely that preferential removal of ${ }^{14} \mathrm{~N}$ with lipid extraction occurred, leading to an enrichment of ${ }^{15} \mathrm{~N}$ in the LE blubber. Further, intact and lipid-extracted blubber samples from 1 post-parturient female were analyzed, and the difference in $\delta^{15} \mathrm{~N}$ values between the 2 was only $0.6 \%$, while the mean difference for 2 nulliparous females was $\sim 1.5 \%$. The parturient female may have been using lipid stores for pup production and/or for milk production (Costa \& Gentry 1986), leading to a lower ratio of lipid to proteinaceous material in her blubber tissues than in the less energetically challenged juvenile males and females, and thus a smaller difference between her LE and NLE blubber $\delta^{15} \mathrm{~N}$ values. The dramatic difference in $\delta^{15} \mathrm{~N}$ values seen in lipid-extracted and intact blubber tissue may not be as evident in lower lipid tissues, but further emphasizes the importance of not considering lipid extraction in isotope analysis.

In summary, non-uniform stable isotope values were evident across a range of tissue types from juvenile male northern fur seals. The consideration of isotope and protein turnover times in different tissues allowed us to make inferences about feeding ecology and geographic movements by sampling multiple tissues from the same individuals at one time. Juvenile males from both St. Paul and St. George Islands were feeding at the same trophic level during summer 1997. Mean 
$\delta^{13} \mathrm{C}$ values supported earlier studies indicating that juvenile male fur seals from St. George Island were feeding at the Bering Sea shelf break, while St. Paul Island males were feeding more over the continental shelf. Juvenile male trophic level appeared to increase with age (from 2 to 3 yr old), and nulliparous and postparturient females seemed to feed at higher trophic levels than juvenile males at all times of the year. NLE blubber samples showed lower $\delta^{15} \mathrm{~N}$ and $\delta^{13} \mathrm{C}$ values than LE blubber. This underscores the need to extract lipid from tissues before isotope analysis to avoid misinterpretation of results.

Acknowledgements. All northern fur seal samples were collected under the National Marine Fisheries Service (NMFS) Permit Number 837. We thank T. Spraker and R. Towell for help with tissue collection, J. Baker and T. Loughlin for logistical support, and T. Maddox at the University of Georgia Institute of Ecology for providing stable isotope analysis. Primary funding was provided by the National Marine Mammal Laboratory (NMML), and the material is based in part upon work supported by the Texas Advanced Research Program under Grant Number 010298-01B. We thank G. Duker, H. Huber, J. Lee, J. Sease, E. Sinclair, T. Zeppelin, and 3 anonymous reviewers for their comments, which helped to improve this manuscript.

\section{LITERATURE CITED}

Ambrose SH, DeNiro MJ (1986) The isotopic ecology of east African mammals. Oecologia 69:395-406

Antonelis GA, Sinclair EH, Ream RR, Robson BW (1997) Interisland variation in the diet of female northern fur seals (Callorhinus ursinus) in the Bering Sea. J Zool 242:435-451

Baker JD, Fowler CW, Antonelis GA (1994) Mass change in fasting immature male northern fur seals. Can J Zool 72:326-329

Bidigare RR, Fluegge A, Freeman KH (1997) Consistent fractionation of ${ }^{13} \mathrm{C}$ in nature and in the laboratory: growthrate effects in some haptophyte algae. Global Biogeochem Cycles 11:279-292

Bigg MA (1986) Arrival of northern fur seals, Callorhinus ursinus, on St. Paul Island, Alaska. Fish Bull 84:383-394

Bigg MA (1990) Migration of northern fur seals (Callorhinus ursinus) off western North America. Can Tech Rep Fish Aquat Sci 1764

Boutton TW (1991) Stable carbon isotope ratios of natural materials. I. Sample preparation and mass spectrometric analysis. In: Coleman DC, Fry B (eds) Carbon isotope techniques. Academic Press, San Diego, p 155-171

Burkhardt S, Riebesell U, Zondervan I (1999) Effects of growth rate, $\mathrm{CO}_{2}$ concentration, and cell size on the stable carbon isotope fractionation in marine phytoplankton. Geochim Cosmochim Acta 63:3729-3741

Burns JM, Trumble SJ, Castellini MA, Testa JW (1998) The diet of Weddell seals in McMurdo Sound, Antarctica as determined from scat collections and stable isotope analysis. Polar Biol 19:272-282

Burton RK, Koch PL (1999) Isotopic tracking of foraging and long-distance migration in northeastern Pacific pinnipeds. Oecologia 119:578-585

Burton RK, Snodgrass JJ, Gifford-Gonzalez D, Guilderson T,
Brown T, Koch PL (2001) Holocene changes in the ecology of northern fur seals: insights from stable isotopes and archaeofauna. Oecologia 128:107-115

Chamberlain CP, Blum JD, Holmes RT, Feng X, Sherry TW, Graves GR (1997) The use of isotope tracers for identifying populations of migratory birds. Oecologia 109:132-141

Cherel Y, Hobson KA, Weimerskirch H (2000) Using stableisotope analysis of feathers to distinguish moulting and breeding origins of seabirds. Oecologia 122:155-162

Costa DP, Gentry RL (1986) Free-ranging energetics of northern fur seals. In: Gentry RL, Kooyman GL (eds) Fur seals: maternal strategies on land and at sea. Princeton University Press, Princeton, NJ, p 79-101

de la Higuera $M$, Akharback H, Hidalgo MC, Peragón J, Lupiáñez JA, García-Gallego M (1999) Liver and white muscle protein turnover rates in the European eel (Anguilla anguilla): effects of dietary protein quality. Aquaculture 179:203-216

DeNiro MJ, Epstein S (1978) Influence of diet on the distribution of carbon isotopes in animals. Geochim Cosmochim Acta 42:495-506

DeNiro MJ, Epstein S (1981) Influence of diet on the distribution of nitrogen isotopes in animals. Geochim Cosmochim Acta 45:341-351

Descolas-Gros C, Fontugne M (1990) Stable carbon isotope fractionation by marine phytoplankton during photosynthesis. Plant Cell Environ 13:207-218

Dobush GR, Ankney CD, Krementz DG (1985) The effect of apparatus, extraction time, and solvent type on lipid extractions of snow geese. Can J Zool 63:1917-1920

Dunton KH (1985) Trophic dynamics in marine nearshore systems of the Alaskan High Arctic. PhD thesis, University of Alaska, Fairbanks

Dunton KH, Saupe SM, Golikov AN, Schell DM, Schonberg SV (1989) Trophic relationships and isotopic gradients among arctic and subarctic marine fauna. Mar Ecol Prog Ser 56:89-97

Ehleringer JR, Rundel PW (1989) Stable isotopes: history, units, and instrumentation. In: Rundel PW, Ehleringer JR, Nagy KA (eds) Stable isotopes in ecological research. Springer-Verlag, New York, p 1-15

Engel MH, Macko SA (1993) Organic geochemistry: principles and applications. Plenum Press, New York

Fantle MS, Dittel AI, Schwalm SM, Epifanio CE, Fogel ML (1999) A food web analysis of the juvenile blue crab, Callinectes sapidus, using stable isotopes in whole animals and individual amino acids. Oecologia 120:416-426

Focken U, Becker K (1998) Metabolic fractionation of stable carbon isotopes: implications of different proximate compositions for studies of the aquatic food webs using $\delta^{13} \mathrm{C}$ data. Oecologia 115:337-343

France RL, Peters RH (1997) Ecosystem differences in the trophic enrichment of ${ }^{13} \mathrm{C}$ in aquatic food webs. Can J Fish Aquat Sci 54:1255-1258

Fry B (1988) Food web structure on Georges Bank from stable C, N, and S isotopic compositions. Limnol Oceanogr 33: 1182-1190

Gaebler OH, Vitti TG, Vukmirovich R (1966) Isotope effects in metabolism of ${ }^{14} \mathrm{~N}$ and ${ }^{15} \mathrm{~N}$ from unlabelled dietary proteins. Can J Biochem Physiol 44:1249-1257

Gannes LZ, O'Brien DM, del Rio CM (1997) Stable isotopes in animal ecology: assumptions, caveats, and a call for more laboratory experiments. Ecology 78:1271-1276

Gannes LZ, del Rio CM, Koch P (1998) Natural abundance variations in stable isotopes and their potential uses in animal physiological ecology. Comp Biochem Physiol A119: 725-737 
Gentry RL (1998) Behavior and ecology of the northern fur seal. Princeton University Press, Princeton, NJ

Gentry R, Holt J, Francis J (1979) Behavior and biology, Pribilof Islands. In: Marine Mammal Division (prepared by) Fur seal investigations, 1978. Northwest and Alaska Fisheries Center Processed Rep. 79-1, p 17-33

Goericke R, Fry B (1994) Variations of marine plankton $\delta^{13} \mathrm{C}$ with latitude, temperature, and dissolved $\mathrm{CO}_{2}$ in the world ocean. Global Biogeochem Cycles 8:85-90

Gervais F, Riebesell U (2001) Effect of phosphorus limitation on elemental composition and stable carbon isotope fractionation in a marine diatom growing under different $\mathrm{CO}_{2}$ concentrations. Limnol Oceanogr 46:497-504

Hare PE, Fogel ML, Stafford TW Jr, Mitchell AD, Hoering TC (1991) The isotopic composition of nitrogen and carbon in individual amino acids isolated from modern and fossil proteins. J Archaeol Sci 18:331-342

Hildebrand GV, Farley SD, Robbins CT, Hanley TA, Titus K, Servheen C (1996) Use of stable isotopes to determine diets of living and extinct bears. Can J Zool 74:2080-2088

Hirons AC, Schell DM, Springer AM (1998) Isotope ratios in Steller sea lions, northern fur seals, and harbor seals of the Bering Sea and Western Gulf of Alaska: trophic implications. In: Schell DM (principal investigator) Testing conceptual models of marine mammal trophic dynamics using nitrogen and carbon stable isotope ratios. OCS Study MMS 98-0031, University of Alaska and Coastal Marine Institute, Fairbanks, AK, p 31-54

Hobson KA (1993) Trophic relationships among high Arctic seabirds: insights from tissue-dependent stable isotope models. Mar Ecol Prog Ser 95:7-18

Hobson KA (1999) Tracing origins and migration of wildlife using stable isotopes: a review. Oecologia 120:314-326

Hobson KA, Clark RG (1992) Assessing avian diets using stable isotopes. I. Turnover of ${ }^{13} \mathrm{C}$ in tissues. Condor 94:181-188

Hobson KA, Schell DM (1998) Stable nitrogen and carbon isotope patterns in baleen from eastern Arctic bowhead whales (Balaena mysticetus). Can J Fish Aquat Sci 55: 2601-2607

Hobson KA, Welch HE (1992) Determination of trophic relationships within a high Arctic marine food web using $\delta^{13} \mathrm{C}$ and $\delta^{15} \mathrm{~N}$ analysis. Mar Ecol Prog Ser 84:9-18

Hobson KA, Piatt JF, Pitocchelli J (1994) Using stable isotopes to determine seabird trophic relationships. J Anim Ecol 63:786-798

Hobson KA, Schell DM, Renouf D, Noseworthy E (1996) Stable nitrogen and carbon isotopic fractionation between diet and tissues of captive seals: implications for dietary reconstructions involving marine mammals. Can J Fish Aquat Sci 53:528-533

Hobson KA, Sease JL, Merrick RL, Piatt JF (1997) Investigating trophic relationships of pinnipeds in Alaska and Washington using stable isotope ratios of nitrogen and carbon. Mar Mamm Sci 13:114-132

Horning M, Trillmich F (1997) Ontogeny of diving behaviour in the Galápagos fur seal. Behaviour 134:1211-1257

Kelly JF (2000) Stable isotopes of nitrogen and carbon in the study of avian and mammalian trophic ecology. Can J Zool 78:1-27

Kurle CM (1998) Stable isotope assessment of temporal and geographic differences in feeding ecology of northern fur seals (Callorhinus ursinus). MS thesis, Texas A\&M University, College Station

Kurle CM (2002) Stable isotope ratios of blood components from captive northern fur seals (Callorhinus ursinus) and their diet: applications for studying the foraging ecology of wild otariids. Can J Zool 80:902-909
Kurle CM, Worthy GAJ (2001) Stable isotope assessment of temporal and geographic differences in feeding ecology of northern fur seals (Callorhinus ursinus) and their prey. Oecologia 126:254-265

Laws EA, Popp BN, Bidigare RR, Kennicutt MC, Macko SA (1995) Dependence of phytoplankton carbon isotopic composition on growth rate and $\left[\mathrm{CO}_{2}\right]^{\text {aq }}$ : theoretical considerations and experimental results. Geochim Cosmochim Acta 59:1131-1138

Lawson JW, Hobson KA (2000) Diet of harp seals (Pagophilus groenlandicus) in nearshore northeast Newfoundland: inferences from stable-carbon $\left(\delta^{13} \mathrm{C}\right)$ and nitrogen $\left(\delta^{15} \mathrm{~N}\right)$ isotope analyses. Mar Mamm Sci 16:578-591

Lehninger AL (1982) Principles of biochemistry. Worth Publishers, New York

Lindstedt S, Prockop DJ (1961) Isotopic studies on urinary hydroxyproline as evidence for rapidly catabolized forms of collagen in the young rat. J Biol Chem 236(5):1399-1403

Macko SA, Estep MF, Hare PE, Hoering TC (1983) Stable nitrogen and carbon isotopic composition of individual amino acids isolated from cultured microorganisms. Carnegie Inst Wash Year Book 82:404-410

Macko SA, Fogel Estep ML, Engel MH, Hare PE (1986) Kinetic fractionation of stable nitrogen isotopes during amino acid transamination. Geochim Cosmochim Acta 50:2143-2146

Macko SA, Fogel-Estep ML, Hare PE, TC Hoering (1987) Isotopic fractionation of nitrogen and carbon in the synthesis of amino acids by microorganisms. Chem Geol 65:79-92

McConnaughey T, McRoy CP (1979) Food-web structure and the fractionation of carbon isotopes in the Bering Sea. Mar Biol 53:257-262

Michener RH, Schell DM (1994) Stable isotope ratios as tracers in marine aquatic food webs. In: Lajtha $\mathrm{K}$, Michener $\mathrm{RH}$ (eds) Stable isotopes in ecology and environmental science. Blackwell Scientific Publications, Oxford, p 138-157

Minagawa M, Wada E (1984) Stepwise enrichment of $\delta^{15} \mathrm{~N}$ along food chains: further evidence and the relation between ${ }^{15} \mathrm{~N}$ and animal age. Geochim Cosmochim Acta 48:1135-1140

Minami H, Ogi H (1997) Determination of migratory dynamics of the sooty shearwater in the Pacific using stable nitrogen and carbon isotope analysis. Mar Ecol Prog Ser 158:249-256

Nakamura K, Schoeller DA, Winkler FJ, Schmidt HL (1982) Geographical variations in the carbon isotope composition of the diet and hair in contemporary man. Biomed Mass Spectrom 9:390-394

Nakatsuka T, Handa N, Wada E, Wong CS (1992) The dynamic changes of stable isotopic ratios of nitrogen and carbon in suspended and sedimented particulate organic matter during a phytoplankton bloom. J Mar Res 50:267-296

Owens NJP (1987) Natural variations in ${ }^{15} \mathrm{~N}$ in the marine environment. Adv Mar Biol 24:389-451

Pancost RD, Freeman KH, Wakeham SG, Robertson CY (1997) Controls on carbon isotope fractionation by diatoms in the Peru upwelling region. Geochim Cosmochim Acta 61:4983-4991

Popp BN, Laws EA, Bidigare RR, Dore JE, Hanson KL, Wakeham SG (1998) Effect of phytoplankton cell geometry on carbon isotopic fractionation. Geochim Cosmochim Acta 62(1):69-77

Rau GH, Sweeney RE, Kaplan IR (1982) Plankton ${ }^{13} \mathrm{C}:{ }^{12} \mathrm{C}$ ratio changes with latitude: differences between northern and southern oceans. Deep-Sea Res 29:1035-1039

Rau GH, Mearns AJ, Young DR, Olson RJ, Schafer HA, Kaplan IR (1983) Animal ${ }^{13} \mathrm{C} /{ }^{12} \mathrm{C}$ correlates with trophic level in pelagic food webs. Ecology 64:1314-1318 
Rau GH, Takahashi T, Des Marais DJ (1989) Latitudinal variations in plankton $\delta^{13} \mathrm{C}$ : implication for $\mathrm{CO}_{2}$ and productivity in past oceans. Nature 341:516-518

Rau GH, Takahashi T, Des Marais DJ, Repeta DJ, Martin JH (1992) The relationship between $\delta^{13} \mathrm{C}$ of organic matter and $\left[\mathrm{CO}_{2}(\mathrm{aq})\right]$ in ocean surface water: data from a JGOFS site in the northeast Atlantic Ocean and a model. Geochim Cosmochim Acta 56:1413-1419

Saino T, Hattori A (1987) Geographical variation of the water column distribution of suspended particulate organic nitrogen and its ${ }^{15} \mathrm{~N}$ natural abundance in the Pacific and its marginal seas. Deep-Sea Res 34:807-827

Saupe SM, Schell DM, Griffiths WB (1989) Carbon-isotope ratio gradients in western arctic zooplankton. Mar Biol 103:427-432

Scheffer VB (1962) Pelage and surface topography of the northern fur seal. N Am Fauna 64:1-206

Scheffer VB, Johnson AM (1963) Molt in the northern fur seal. US Fish Wildl Serv Spec Sci Fish 450:1-34

Schell DM (2000) Declining carrying capacity in the Bering Sea: isotopic evidence from whale baleen. Limnol Oceanogr 45:459-462

Schell DM, Saupe SM, Haubenstock N (1989) Natural isotope abundances in bowhead whale (Balaena mysticetus) baleen: markers of aging and habitat usage. In: Rundel PW, Ehleringer JR, Nagy KA (eds) Stable isotopes in ecological research. Springer-Verlag, New York, p 260-269

Schell DM, Barnett BA, Vinette KA (1998) nitrogen and carbon isotope ratios in zooplankton of the Bering, Chukchi and Beaufort Seas. Mar Ecol Prog Ser 162:11-23

Schimel DS (1993) Theory and application of tracers. Academic Press, San Diego

Schoenheimer R (1942) The dynamic state of body constituents. Harvard University Press, Cambridge, MA

Sinclair EH, Loughlin T, Pearcy W (1994) Prey selection by northern fur seals (Callorhinus ursinus) in the eastern Bering Sea. Fish Bull 92:144-156

Editorial responsibility: Jennifer Purcell (Contributing Editor), Anacortes, Washington, USA
Sinclair EH, Antonelis GA, Robson BW, Ream RR, Loughlin TR (1996) Northern fur seal, Callorhinus ursinus, predation on juvenile walleye pollock, Theragra chalcogramma. NOAA Tech Rep NMFS 126:167-178

Smith RJ, Hobson KA, Koopman HN, Lavigne DM (1996) Distinguishing between populations of fresh- and saltwater harbour seals (Phoca vitulina) using stable-isotope ratios and fatty acid profiles. Can J Fish Aquat Sci 53: $272-279$

Springer AM, McRoy CP, Flint MV (1996) The Bering Sea green belt: shelf-edge processes and ecosystem production. Fish Oceanogr 5:205-223

Thompson RC, Ballou JE (1956) Studies of metabolic turnover with tritium as a tracer. V. The predominantly nondynamic state of body constituents in the rat. J Biol Chem 223:795-809

Tieszen LL (1978) Carbon isotope fractionation in biological material. Nature 276:97-98

Tieszen LL, Boutton TW, Tesdahl KG, Slade NA (1983) Fractionation and turnover of stable carbon isotopes in animal tissues: implications for ${ }^{13} \mathrm{C}$ analysis of diet. Oecologia 57: 32-37

Tortell PD, Rau GH, Morel FMM (2000) Inorganic carbon acquisition in coastal Pacific phytoplankton communities. Limnol Oceanogr 45:1485-1500

Wada E, Terazaki M, Kabaya Y, Nemoto T (1987) ${ }^{15} \mathrm{~N}$ and ${ }^{13} \mathrm{C}$ abundances in the Antarctic Ocean with emphasis on the biogeochemical structure of the food web. Deep-Sea Res 34:829-841

Wada E, Mizutani H, Minagawa M (1991) The use of stable isotopes for food web analysis. CRC Crit Rev Food Sci Nutr 30:361-371

Waterlow JC, Garlick PJ, Millward DJ (1978) Protein turnover in mammalian tissues and in the whole body. NorthHolland Publishing, Amsterdam

Welle S (1999) Human protein metabolism. Springer-Verlag, New York

Submitted: April 11, 2001; Accepted: October 14, 2001

Proofs received from author(s): June 7, 2002 